\title{
RECLAIMING URBAN SPACE: A STUDY OF COMMUNITY GARDENS IN POZNAŃ
}

\author{
Barbara Maćkiewicz ${ }^{1}$, Raúl Puente Asuero ${ }^{2}$, Krystyna Pawlak $^{1}$ \\ ${ }^{1}$ Institute of Socio-Economic Geography and Spatial Management, Faculty of Geographical and Geological \\ Sciences, Adam Mickiewicz University, Poznań, Poland \\ ${ }^{2}$ Department of Geography, History and Philosophy, Pablo de Olavide University, Seville
}

Manuscript received: October 17, 2018

Revised version: November 26, 2018

\begin{abstract}
MaćKiewicz B., Puente Asuero R., Pawlak K., 2018. Reclaiming urban space: A study of community gardens in Poznań. Quaestiones Geographicae 37(4), Bogucki Wydawnictwo Naukowe, Poznań, pp. 131-150. 2 tables, 7 figs, 6 pictures.

ABstRact: In this paper, we discuss the presence of community gardens in urban spaces and the types of activities performed there, using the city of Poznan as a case study. First, based on interviews with representatives of selected non-governmental organisations, analyses of available Internet sources as well as our own field research, cartographic and photographic documentation, we identify community gardens in the space of the city and explore their formation process. In the course of our study we also concentrate on the type of garden location. In addition, we devote our attention to the gardens which have disappeared from the fabric of the city. Our study reveals that community gardens currently operating in Poznań are established in non-central locations. These gardens are scattered in various parts of the city. Only in the Łazarz district there are two community gardens. Most frequently, community gardens are established on plots between old blocks of flats and tenement houses. Two gardens are located on underdeveloped greenery near the Warta River and in two city parks. A detailed examination of the events held in the community gardens in the Eazarz district in the years 2014-2017 shows that they had a very diversified character. Both of them turned out to be multifunctional, i.e. hosted meetings devoted to agriculture and horticulture, environmental education, artistic events, DIY and recreation. However, the percentage of events in the structure of the meetings organised in the gardens differed considerably.
\end{abstract}

KEY WORDS: community gardens, urban agriculture, urban space, Poznań

Corresponding author: Barbara Maćkiewicz, Institute of Socio-Economic Geography and Spatial Management, Adam Mickiewicz University, Poznań, B. Krygowskiego 10, 61-680 Poznań, Poland; e-mail: basic@amu.edu.pl

\section{Introduction}

Contemporary forms of urban gardening are shaped by different actors, from individual persons to whole communities (Caputo et al. 2016). Community gardens belong to the category of those managed collectively by people. Inspired by the US gardens of the 1970s, Latin American urban agriculture, and such movements as Transition Towns and Guerrilla Gardening, community gardens in Europe started to appear quite recently, i.e. in the first decade of the 21st century (Sondermann et al. 2016; Fernández, Morán 2015; Rosol 2012a). Most of them are bottom-up initiatives on the part of local communities. They are characterised by being planned and managed by joint efforts of community groups usually made up by residents, local city activists that first occupy brownfields or other empty urban spaces and only then start to gain the official administrative support within the scope of administration, finances, logistics and law (Sondermann et al. 2016). The distinguishing feature of community gardens is their open character. In the majority of cases it means constant and full availability to the public at large. As regards community gardens, residents not only decide on how to use the empty spaces of plots but they also assume 
responsibility for creating and tending to green belts (Rosol 2012b). Even though these are usually small areas equipped with poor infrastructure, they host a variety of different social activities.

In Poland, community gardens started to emerge just a few years ago (Kałużna, Mizgajski 2016; Skrzypczak 2017a). Although it is impossible to establish the exact beginning, they certainly appeared after 2010. So far Polish community gardens have not received sufficient attention neither in Polish nor in foreign publications. There is a considerable dearth of scholarly works on the subject matter related to Polish community gardens. Basically, there are only: a study describing the implementation of the programme Our Community Garden (Nasz Ogród Społeczny) by Green Cross Poland (Kałużna, Mizgajski 2016), works concerning Warsaw local communities (Skrzypczak 2017a, 2017b) as well as materials on some selected initiatives of establishing Polish community gardens (Latkowska 2016). In addition, some mention must be made of sparse publications which refer to community gardens in Poland when discussing allotment gardens, commoner and deeper-rooted in our Polish tradition (for instance Caputo et al. 2016; Sondermann et al. 2016). Nevertheless, no single work has been prepared that would approach the topic of development and functioning of community gardens in the space of a big Polish city in a comprehensive and multidimensional manner. The present article aims to fill the gap in this knowledge to some extent at least. A case study of Poznan allowed the authors to keep trace of the development of community gardens, to identify their initiators as well as to characterise the specific types of their locations. Furthermore, thanks to examining the subject matter of meetings organised in community gardens in the district of Łazarz, it was possible to determine the character of the events held there and, subsequently, compare the activities undertaken.

\section{Putting community gardens into context}

\section{The big picture - community gardening ideas}

Community gardens are part of the list of urban agriculture spaces that we can find in the

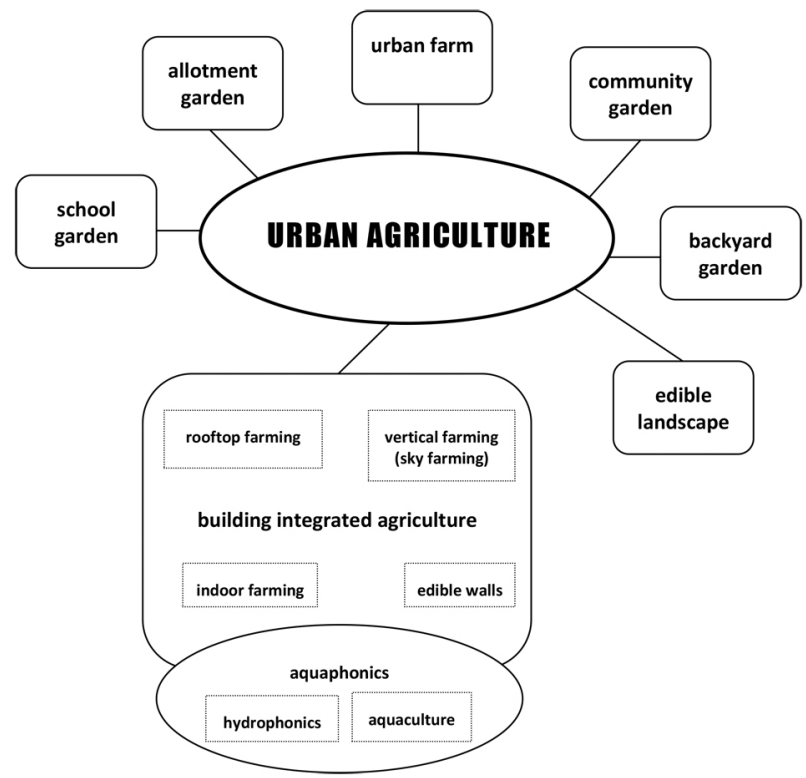

Fig. 1. Scope of urban agriculture.

Source: own compilation on the basis of Johns Hopkins Center.

cities of the world. Thereby, the Johns Hopkins Center for a Livable Future (CLF) - an academic centre housed in the Bloomberg School of Public Health's Department of Environmental Health Sciences - provides an overview of the urban agriculture in which community gardens are presented (Fig. 1).

Considering community gardens as one of the types of urban agriculture, we can currently understand that a community garden is any piece of land gardened by a group of people utilising shared plots on private or public land. Likewise, these are outdoor socialisation centres, natural spaces, leisure spaces and educational spaces.

Currently, there is no single coherent theory pertaining to the subject matter of community gardens. In practice, this topic comprises theoretical, methodological and instrumental aspects deriving from various social, economic, ecological and spatial disciplines. Scholarly works helping to shape the theories concerning community gardens can be divided into three major research currents (Smit et al. 1996; Reyburn 2002). First, there is research on the contemporary city, emphasising especially aspects of its social and environmental unsustainability. It is mostly adopted by architects, urban planners, geographers, sociologists and ecologists (Moran, Fernández 2012). Second, the issue of urban/suburban agriculture as well as allotment/community gardens 
is addressed by anthropologists, ethnologists, sociologists or social geographers (Boukharaeva, Marloie 2010). Lastly, the analysis of urban food systems, within the subject matter of which, agroecology and the issue of food sovereignty are developed to reflect the problems that occur when not all city residents have access to safe and nutritious diet following their cultural preferences. This research current is developed mostly by agronomists, economists and dieticians (Aubry, Pourias 2013; Bredley, Galt 2014; Shillington 2013; Tornaghi 2017, to cite just a few).

The city is one of the most complex and heterogeneous creations of mankind. Throughout centuries, the city has proved to have a great capacity for evolutions, transformations and adaptations, which poses difficulties for researchers and scientists striving to understand and analyse its current and future condition. In 2030, according to the UN forecast, the world population will reach the number of 9 billion inhabitants, out of which two thirds, i.e. 6 billion people (twice as many as today) will live in cities. From this perspective, societies are urban and the urban lifestyle is highly expanding. One could say that it is almost colonialism which imposes, step by step or even by leaps, the lifestyle characteristic of cities in rural environments accustomed to traditional ways of living. The global urban community is subject to homogenisation: the same ways and styles of living, the same habits, clothes, and technological devices as well as the same gastronomy and way of thinking. In this way, as Toledo and Barrera-Bassols (2008) claim, the homogenic character of globalisation poses a threat to all manifestations of diversity and "the city, which used to be a creation uniting common languages, codes and fabrics of society is becoming a product: society is disappearing and neighbourly bonds are getting disintegrated" (Lefebvre 1972: 85).

Nevertheless, in view of the pervasive urban homogenisation, there occur simultaneous processes of re-agragrianisation and appreciation of different kinds of agriculture which go counter to the aforesaid tendency. In accordance with the conception of urban and suburban agriculture, a vast and complex range of activities connected with the food production in cities is developing. The processes of re-agrarianisation in cities frequently occur in areas which are either underestimated or devoid of value for housing, commercial or industrial investments. Activities towards re-agrarianisation are undertaken mostly by neighbouring communities or non-governmental organisations which seek new meeting places. Thanks to this, they restore the value of a given space, revitalise their districts and closest surroundings. What is prioritised in community gardens is social cooperation rather than individualism; nature and ecology are opposed to the overwhelming and monotonous city that imposes the dictatorship of bricks and asphalt. Community gardens are the reflection of the society and citizens who form them; therefore it is possible to encounter a great variety of their kinds - from botanical gardens to microparks, family gardens, educational gardens, social

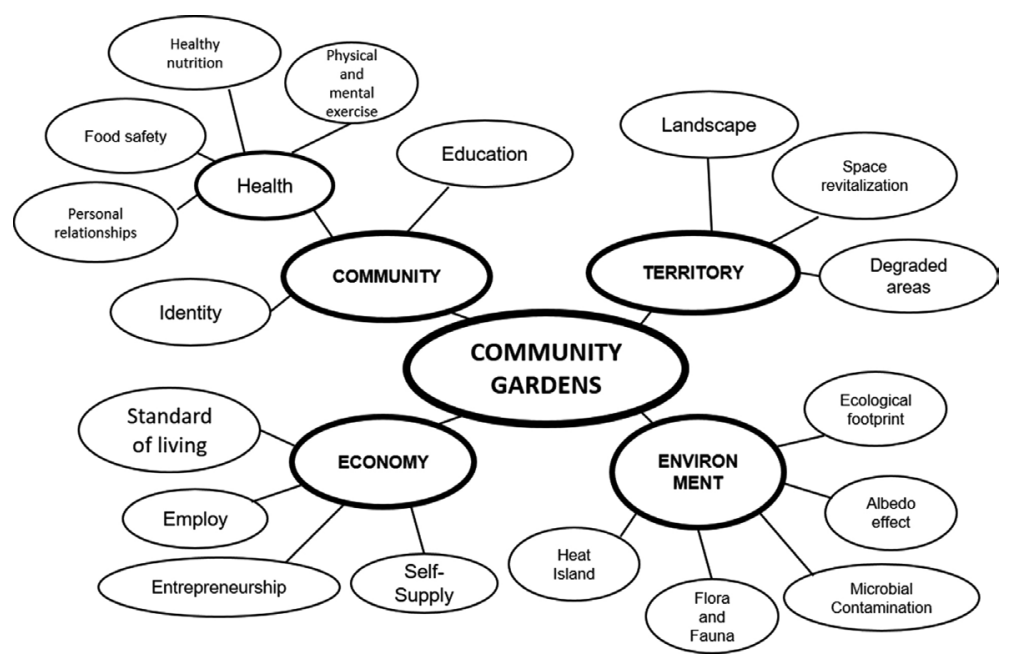

Fig. 2. Multifunctionality of community gardens. Source: own compilation. 
gardens, gardens for pensioners and therapeutic gardens (Busquets, Fàbregas 2008). But it is in this heterogeneity and social diversity that their strength is to be found; this is so because these are spaces where different generations, cultures and socio-economic classes meet. Community gardens have become strategic players when it comes to the future of some free urban spaces (industrial areas, wasteland, unused backstreets, old heaps etc.). Numerous debates on the topic of the city model begin in community gardens and reach the level of local, regional or even national policy. Therefore community gardens are not only areas for vegetable growing, but also constitute cultural and political spaces which serve to build social bonds and are generators of new projects for the whole city (McKay 2011). There is an agreement as to the functions community gardens can perform and benefits they can bring to contemporary cities. Those functions are: social, economic, territorial and environmental. Fig. 2 gives a comprehensive frame of reference.

In the available state-of-the-art literature, one can find a description of the functions and multidimensionality of urban agriculture. The diagram by Canadian researcher Eric Duchemin (2009) is worth paying attention to. It connects urban agriculture with education, urban management, economic development, rest and health, food security, natural environment and social relations (Fig. 3).
Community gardens bring a host of positive consequences to cities and their residents:

1. From a social point of view, community gardens contribute to the improvement of life quality as they offer an opportunity for rest and recreation. Social bonds strengthen as a result. Community gardens are places where neighbours discuss not only agricultural issues but also current matters and personal problems. These gardens frequently replace such meeting spots as squares, bars or shopping centres, which also limits the possibility, for instance, of drinking alcohol, smoking cigarettes or gambling. From the educational perspective, community gardens foster multidirectional education (people learn from one another) and intergenerational learning (adults share their knowledge with children). As regards physical and mental health, community gardens offer the possibility of light physical and mental activity as well as contribute to an increase in the number of consumed vegetables, which improves the eating habits of city residents.

2. From the economic perspective, for cities with high unemployment rates, community gardens may become training places for young unemployed people who want to engage in ecological gardening. On the other hand, immigrants and people who are marginalised have an opportunity to integrate with the community.

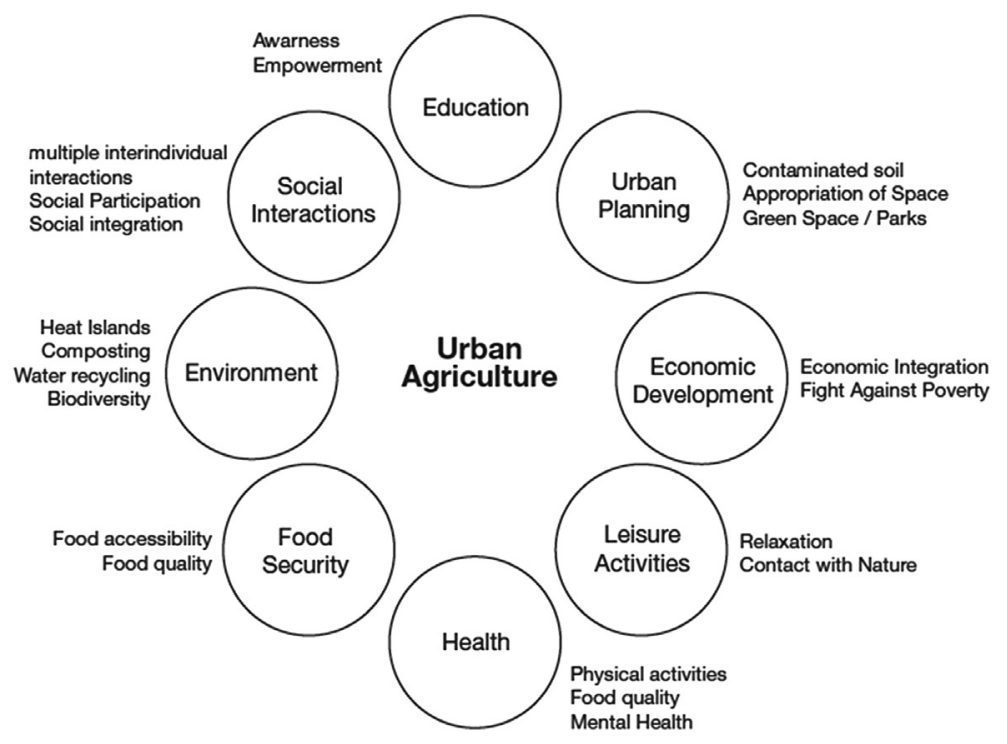

Fig. 3. Multidimensionality of urban agriculture. Source: Duchemin et al. 2009. 
3. From the territorial perspective, community gardens support revitalisation of unused and/or degraded urban spaces. In many cases, community gardens can occupy empty urban areas in a state of considerable environmental degradation, abandoned or used for a harmful activity (illegal dumpsites, disused brownfields, e.g. old industrial plants, abandoned plots etc.).

4. From the environmental perspective, urban gardens contribute to minimising the effect of heat islands in the urban climate and support the ecological balance of natural cycles of water and soil.

Although urban agriculture still remains a residual, marginal and interstitial practice, fraught with contradictions and troubled by constraints (Tornaghi 2017: 782), the spread of community gardens and other forms of urban agriculture in the cities of the global North indicates that in the future it will no longer be something weird or marginal. Debates concerning food sovereignty, the participatory management of urban spaces, an economy of solidarity and social ecology intertwine and reach the highest spheres of political and economic power through the process of capillarity.

\section{The Polish context - fashion for collective development of gardens}

In contrast to traditional allotment gardening which has an over one-hundred-year-long history and a well-established position, community gardens in Poland constitute a new phenomenon (Kałużna, Mizgajski 2016; Skrzypczak 2017a). Although allotment gardens fulfil social, economic and ecological functions, in reality their accessibility for the general public is very restricted (Orzechowska-Szajda, Podolska 2013). Since they are assigned to an individual user, surrounded by a fence and locked, a large number of urbanites in Poland have no access to them (Speak at al. 2015; Skrzypczak 2017a). In addition, allotment gardens have recently changed their function and are now used mostly as areas for passive recreation and not for growing food (Kałużna, Mizgajski 2016; Giedrych, Poniży 2013; Szkup 2013).

It is also known that in Polish cities there is a dearth of controlled green areas. According to the standards of the World Health Organisation, there should be $50 \mathrm{~m}^{2}$ of this type of area per one resident of an agglomeration. However, in Polish cities which are regional centres, the controlled green area ranges from $38.7 \mathrm{~m}^{2}$ in Bydgoszcz (the highest ratio) to $13.7 \mathrm{~m}^{2}$ in Szczecin (Maćkiewicz, Szczepańska 2017). Furthermore, when discussing new housing investments, city residents' needs for contact with the environment are not usually taken into consideration and very limited greenery is provided to new occupants, i.e. lawns or small flower beds (Pokorski, Siwiec 1998; Maćkiewicz at al. 2018).

The issues mentioned above undoubtedly contribute to the observed dynamic development of a new form of urban gardening in Poland, namely community gardens. They form additional green areas in cities, which allow the utilisation of wasteland, neglected or even degraded areas. Although it is worth remembering that thanks to the established legal regulations - guaranteed by the Act on Family Allotment Gardens of 13th December 2013 (Journal of Laws of 2014, item 40) - the position of allotment gardens in the urban space is more stable in comparison to community gardens, which can be used only for a certain period. In contrast to allotments, where each garden holder cultivates his or her own plot individually, in community gardens a group of people works together. It helps to make new contacts and strengthen relationships. It is very significant since community gardens are usually a meeting place for local activists and people living in the vicinity of the garden (Latkowska 2012; Kałużna, Mizgajski 2016; Skrzypczak 2017b). They are open mostly to the general public, which means that all people can use them if they follow the established rules and want to tend to plants and relax in urban greenery. Ecological farming as well as large-scale recycling are undertaken in community gardens. In this way, people are taught how to care for the natural environment and protect natural resources. Plants are often grown in various recycled containers. Moreover, the garden is usually furnished with recycled materials as well (Latkowska 2012, 2016; Skrzypczak 2017a).

As mentioned above, community gardens have been developing in Poland for only a few years. The exact beginnings are difficult to establish but they certainly emerged after 2010 . 
Single initiatives of this kind have proved so inspiring for many local communities that currently we can even start talking about a certain fashion for creating urban community gardens. As Skrzypczak (2017a: 2) claims, we can observe not just an emergence of a new approach to urban greenery but a form of social mechanism which can be repeated in various places. Support for this type of initiatives is also received from different types of projects - both nationwide (e.g. Our Community Garden (Nasz Ogród Społeczny), Cultural Wasteland (Nieużytki Sztuki), Green Bench (Zielona Ławeczka) and local, e.g. Nowa Huta Gardens (Ogrody Nowej Huty) - as well as contests, e.g. Social Initiative for the Environment (Inicjatywy Obywatelskie dla Środowiska) financed by National Fund for Environment Protection and Water Management (Narodowy Fundusz Ochrony Środowiska i Gospodarki Wodnej). In addition, funds are collected by means of local initiatives, participatory budgets or crowdfunding (Latkowska 2016).

As regards initiatives concerning community gardens which embrace the area of the whole country, there is one, launched in 2014 by Green Cross Poland, which deserves special attention - Our Community Garden. It is a programme for awarding grants for establishing community gardens (Kałużna, Mizgajski 2016). Neighbouring communities can apply for various kinds of support for matters related to the gardens themselves and to the development of neighbourly dialogue. As part of this enterprise, an Internet portal (www.naszogrodspeleczny.pl) was created as well as a guide describing step by step the necessary actions that must be taken to establish a community garden. The major goals of the programme - Our Community Garden - are the following: aid in building local social capital in cities, improving the urban aesthetics in the public space, sharing expertise on horticulture and biological processes taking place in soil, supporting food sovereignty, providing local groups with tools and counselling. During the pilot stage of the project, 10 community gardens were created in different parts of Poland, including, for instance, the first community garden in the Lubuskie Province ('Short Street' Community Garden - Ogród Społeczny Krótka) in Gorzów Wielkopolski and Gdańsk ('Reduta' Centre Garden - Ogród Centrum Reduta). By the middle of 2016, another 16 gardens were established and 7 more were in the initial phase of organisation (Kałużna, Mizgajski 2016, www. naszporatlspołeczny.pl).

Another interesting nationwide project promoting community gardening is the one by an artist E. Jabłońska (Cultural Wasteland - Nieużytki Sztuki) cofinanced by the Ministry of Culture and National Heritage in 10 cities (Białystok, Gdańsk, Lublin, Łódź, Olsztyn, Tarnów, Warszawa, Wrocław, Zielona Góra) that concerns a free-ofcharge lease of green belts, lawns and some areas adjoining public galleries and museums. It is a proposal for the public to engage in the process of intervention not only in the city space but also in the sphere of art. Providing residents, neighbours and the public at large with access to areas belonging to galleries or museums may become, in consequence, the beginning of the process of creating new spaces for meeting based on mutual exchange fostering cooperation and joint responsibility in action (Latkowska 2016, www.nieuzytkisztuki.elajablonska.com).

Out of all current local initiatives in Poland related to community gardens, it is necessary to give special prominence to the project by Nowa Huta Gardens organised by the C.K. Norwid Culture Centre in Cracow in cooperation with the international steel and mining company ArcelorMittal S.A. and under the auspices of the President of Cracow and the Chairman of the Municipal Council. This initiative aims at popularising knowledge about horticulture, ecology as well as promoting the integration of local communities around the idea of urban greenery. The project is addressed to the residents and all well-wishers of the district. The actions undertaken open up an opportunity for meetings and common activities of, among others, adolescents, families with children and senior citizens. The major task of the participants in the project in a given year is common work on the establishment of two community gardens in the area of Nowa Huta, one of Cracow's districts. They have created twelve gardens so far (Latkowska 2016, www. ogrodynh.pl).

Even though the trend for the development of community gardens in Poland is increasingly noticeable, no official and exhaustive record of all existing gardens has been developed so far. An attempt at marking all community gardens on 
the map of Poland was made by the Internet portal Our Community Garden (Kałużna, Mizgajski 2016). The actual number of gardens, however, is considerably higher than the one presented there. It must be emphasised though that creating an exhaustive record of community gardens would be very difficult as only some of them have their own Internet websites. Furthermore, in the case of some gardens only a limited number of people know about their existence and the information about them can be obtained via such social networking sites as facebook.com. Nonetheless, it seems that the greatest number of community gardens are situated in Warsaw, although it cannot be stated with absolute certainty because of the above-mentioned reasons. There can be found 21 gardens of the type, for instance, Hoe and Sun (Motyka i Stońce), Bem Fort (Fort Bema), 'Shrub' Community (Spótdzielnia Krzak), Rose Spade (Różany Szpadel), and their unusual names point to the creativity of their founders (Latkowska 2016, www.bujnawarszawa.pl, www.um.warszawa.pl, warszawa.naszemiasto.pl). Warsaw community gardens are created by informal groups, but also by societies and institutions. Support for Warsaw gardens is also offered by the Greenery Board (Zarzad Zieleni), municipal organisational unit from the capital city of Warsaw. Taking into consideration the scale of the whole area, it seems that community gardens in the capital are the best organised of all the Polish cities. Warsaw gardeners have their own Internet website - www.bujnawarszawa.pl - which presents some basic information about Warsaw community gardens, including a map showing their locations. Furthermore, there is the Flying School of Urban Gardeners (Latajaca Szkoła Ogrodników Miejskich) in the capital city which offers free-of-charge workshops and counselling both for people engaged in tending to community gardens and for groups planning to create new ones. In addition, there is an Open Warehouse of Horticultural Materials (Otwarty Skład Materiatów Ogrodniczych) in Warsaw, which functions as a platform by means of which social garden initiatives can obtain and share various kinds of stock (e.g. equipment, seeds, building materials). Since 2017, Warsaw Community Garden Harvest Festivals have been organised during which various workshops, presentations and contests take place.

\section{Study: Community gardens in Poznań}

\section{Methods}

The study concerned all community gardens (14) which were established and designed in Poznan in the years 2013-2017. At first, 4 individual in-depth interviews were carried out with representatives of the Generator Malta project and members of the 'Bathing Beach' Collective Association (Stowarzyszenie Kolektyw Kapielisko) involved in the development and management of community gardens in Poznań. The interviews took the form of a direct talk which lasted around 60-90 minutes. The questions concerned, among others, the origins of community gardens, the founders and first initiatives, the modes of communication between the users of community gardens, the location and management of the gardens. The next step involved the analysis of social networking websites which publish information on upcoming and past events. Thanks to a detailed analysis of Internet portals, message boards and social networking sites, it was possible to obtain first-hand information and to collect quantitative data about meetings having, among others, horticultural, recreational, artistic, entrepreneurial or educational character. A considerable amount of significant information for the research in question was obtained from meetings in the community gardens. It was also then when an inventory of garden infrastructure as well as cartographic and photographic documentation were made. In addition, in order to understand the specificity of community gardening, a comprehensive analysis of the state-of-the-art literature was conducted. At the final stage of the study, interviews with the same people were repeated using an analogical formula to the first one. The questions concerned the future of community gardens, existing and potential threats, financial issues as well as cooperation with non-governmental organisations and the city authorities. In total, 8 in-depth interviews were conducted and recorded from October 2016 to August 2018.

\section{Origins, location and current situation}

\section{Early beginnings - Generator Malta}

The trend of community gardening, new to Poland, emerged for the first time in Poznan 
thanks to the programme - Generator Malta which was launched as part of the Malta Festival Poznań ${ }^{1}$ in 2013. Apart from the concert stage, dance and theatrical performances, the Malta Festival also opens up space for dialogue, sharing experience and new ideas. In 2013, as part of the project Generator Malta: People-City-Culture, a platform for creativity, exchange of ideas, art, fun and mutual cooperation was created at Liberty Square (Plac Wolności). It was there where the creation of a makeshift, mobile community garden began. In addition, health food zones, artistic workshops and places to actively spend free time were created. It all aimed to spur the local community into action and as such involved the joint creation of public space, for instance, by participating in planting and tending to plants (Pawlak 2017, http://malta-festival.pl, https://generatormalta.wordpress.com).

"As we can see, Generator and its programme propagates the idea of cultivation (Lat. cultus agri). The essence of it is spending time together and creating something together. The initial idea of Generator Malta was to create around 10 gardens. It was a kind of experiment for residents and the initiators of the event because it was not certain whether a given garden will continue to exist". (Interview 1, 2016)

The gardens were to be established in degraded areas lowering the life quality of city-dwellers, in places requiring revival and revitalisation. In order to find areas in the greatest need of corrective actions, residents themselves were asked for help. Publicising the campaign in the press, the media, local restaurants, neighbouring clubs and schools drew a considerable number of people interested in creating community gardens. These were both people willing to see changes in the

The Malta International Theatre Festival is one of the most important cultural events in East-Central Europe. It has been held in Poznań during summer season since 1991. At first, the festival aimed at promoting Polish outdoor, unconventional and experimental theatres. In the course of time, the scope of activities of the project started to comprise other spheres as well. Since 2010 the subject matter of the festival has been revolving around the topics important for understanding the contemporary world, especially Europe, its culture, social situation and the future. vicinity of their homes as well as ordinary urban allotment holders attracted by the subject matter of gardening. Thanks to exploratory walks with residents around the districts of Poznań, a list of places for potential operation was compiled. Afterwards, the organisers of the programme analysed the legal status of these places and selected areas which belonged to the city and private land spots the owners of which were unavailable and did not care. In the conducted voting, the residents from each of the districts chose one out of the three areas singled out by organisers. As was already mentioned, the project aimed at establishing 10 community gardens; yet, because there were only a few organisers from the Generator Malta programme, only 6 locations were eventually selected in the following districts: Śródmieście, Łazarz, Wilda, Jeżyce, Śródka, Chwaliszewo (Table 1).

A significant role in the process of founding the gardens was played by local partners who supported the activities of Generator Malta by granting access to equipment and tools. Each garden received support on the partnership principle. In the case of the Łazarz Garden it was the 'Circle' Residents' Club (Klub Osiedlowy Krag) as well as local scouts and in the case of the Wilda district it was the Wilda Estate Council (Rada Osiedla Wilda). They helped to organise, establish and construct gardens as well as to acquire the elements needed. A municipal budget entity - the Urban Greenery Board was involved to a large extent providing street furniture, e.g. benches. Furthermore, the residents themselves (mostly families with children, scouts, passionate gardeners) had also contributed to the establishment of the gardens. As regards informing residents about the project of creating community gardens, taking their suggestions and opinions, help in this respect was received from students from the Institute of Ethnology and Cultural Anthropology (UAM) as well as from the Academic Circle of AMU Sociology Students. In the summer season of 2013, numerous picnics and meetings devoted to horticulture were held in the 6 community gardens initiated by Genarator Malta.

"As we remember residents came with small pots and cartons of yoghurt to plant together such species as Atlantic giant pumpkin, ornamental 
Table 1. Community gardens established and planned in Poznań in 2013-2017.

\begin{tabular}{|c|c|c|c|c|c|c|}
\hline $\begin{array}{l}\text { Name of com- } \\
\text { munity garden }\end{array}$ & \begin{tabular}{|c|} 
Year of \\
estab- \\
lishment
\end{tabular} & Initiator & Initiator type & Location type & City district & $\begin{array}{l}\text { Current } \\
\text { status }\end{array}$ \\
\hline $\begin{array}{l}\text { Liberty Square } \\
\text { Garden }\end{array}$ & 2013 & Generator Malta* & NGO & $\begin{array}{l}\text { large urban square devoid } \\
\text { of greenery }\end{array}$ & centre & inactive \\
\hline \begin{tabular}{l|} 
Chwaliszewo \\
Garden
\end{tabular} & 2013 & Generator Malta & NGO & $\begin{array}{l}\text { green belt close to Warta } \\
\text { river }\end{array}$ & $\begin{array}{l}\text { Chwalisze- } \\
\text { wo }\end{array}$ & inactive \\
\hline Jeżyce Garden & 2013 & Generator Malta & NGO & $\begin{array}{l}\text { pedestrian crossing close to } \\
\text { abandoned building - kiosk }\end{array}$ & Jeżyce & active $^{* *}$ \\
\hline Łazarz Garden & 2013 & Generator Malta & NGO & $\begin{array}{l}\text { area in between residential } \\
\text { blocks }\end{array}$ & Łazarz & active \\
\hline Wilda Garden & 2013 & Generator Malta & NGO & $\begin{array}{l}\text { abandoned and neglected } \\
\text { plot between old tenements }\end{array}$ & Wilda & active \\
\hline $\begin{array}{l}\text { Bez Ogródek } \\
\text { later Sródka } \\
\text { Republic }\end{array}$ & 2013 & Generator Malta & NGO & $\begin{array}{l}\text { small square close to cafe - } \\
\text { Café La Ruina (partner } \\
\text { project) }\end{array}$ & Śródka & inactive \\
\hline $\begin{array}{l}\text { 'Bathing } \\
\text { Beach' } \\
\text { Collective }\end{array}$ & 2014 & $\begin{array}{l}\text { 'Bathing Beach' } \\
\text { Collective Associ- } \\
\text { ation }\end{array}$ & $\begin{array}{c}\text { NGO, } \\
\text { non-profit }\end{array}$ & $\begin{array}{l}\text { green area at closed } \\
\text { summer urban swimming } \\
\text { pool }^{* * *} \text { - area in city park - } \\
\text { Jan Kasprowicz Park }\end{array}$ & Łazarz & active \\
\hline $\begin{array}{l}\text { Nad Potokiem } \\
\text { Community }\end{array}$ & 2014 & $\begin{array}{c}\text { Edible Poznań } \\
\text { Project**** }\end{array}$ & NGO & $\begin{array}{l}\text { area between old residential } \\
\text { blocks }\end{array}$ & Sołacz & active \\
\hline $\begin{array}{l}\text { Wirydarz } \\
\text { Community } \\
\text { on Wzgórze } \\
\text { Reformatów }\end{array}$ & 2016 & $\begin{array}{l}\text { Edible Poznań } \\
\text { Project }\end{array}$ & NGO & $\begin{array}{l}\text { area next to socio-edu- } \\
\text { cational centre for deaf } \\
\text { children }\end{array}$ & Śródka & active \\
\hline $\begin{array}{l}\text { Mozaika Com- } \\
\text { munity }\end{array}$ & 2017 & $\begin{array}{l}\text { Abrys Company } \\
\text { together with } \\
\text { "Osiedle Mło- } \\
\text { dych" }\end{array}$ & $\begin{array}{l}\text { private com- } \\
\text { pany together } \\
\text { with housing } \\
\text { cooperative }\end{array}$ & $\begin{array}{l}\text { area between old residential } \\
\text { blocks }\end{array}$ & $\begin{array}{l}\text { Nowe } \\
\text { Miasto }\end{array}$ & active \\
\hline $\begin{array}{l}\text { Grunwaldzki } \\
\text { Community } \\
\text { Garden }\end{array}$ & 2017 & private person ${ }^{* * * * *}$ & $\begin{array}{l}\text { within frame- } \\
\text { work of } \\
\text { Poznań Partici- } \\
\text { patory Budget }\end{array}$ & $\begin{array}{l}\text { premises of Jan Heweliusz } \\
\text { Park }\end{array}$ & Grunwald & active \\
\hline $\begin{array}{l}\text { Szeląg } \\
\text { Beach-Garden }\end{array}$ & 2017 & 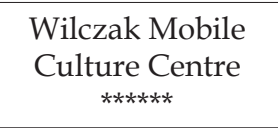 & $\begin{array}{l}\text { NGO, non } \\
\text {-profit }\end{array}$ & $\begin{array}{l}\text { green belt near urban beach } \\
\text { Na Szelągu close to Warta } \\
\text { River }\end{array}$ & Wilczak & active \\
\hline- & - & $\begin{array}{l}\text { Edible Poznań } \\
\text { Project }\end{array}$ & NGO & - & Piątkowo & planned \\
\hline- & - & $\begin{array}{l}\text { Edible Poznań } \\
\text { Project }\end{array}$ & NGO & - & Winiary & planned \\
\hline
\end{tabular}

*the Generator Malta programme operates as part of the Malta Festival.

**active but with the horticultural function being increasingly insignificant.

*** at the moment of creating the 'Bathing Beach' Collective community garden, the summer city swimming pool in Kasprowicz Park in Poznań was abandoned and closed; at present, the facility is modernised and available to residents.

**** the project Edible Poznań operates as part of the Foundation for the Preservation of Historic and Natural Monuments.

***** an idea submitted by a private person within the framework of the Poznań Participatory Budget (Poznański Budzet Obywatelski - PBO) at present Grunwaldzki Community Garden it is at the discretion of the municipal budget entity, i.e. the Urban Greenery Board (Zarzad Zieleni Miejskiej).

****** activities initiated by an NGO and the non-profit organisation the Wilczak Mobile Culture Centre (Mobilny Dom Kultury Wilczak). Currently they are coordinated by a private person, Inspirator Fundation (Fundacja Inspirator) and the Poznan Centre for Local Initiatives (Centrum Iniciatyw Lokalnych).

Source: own compilation. 


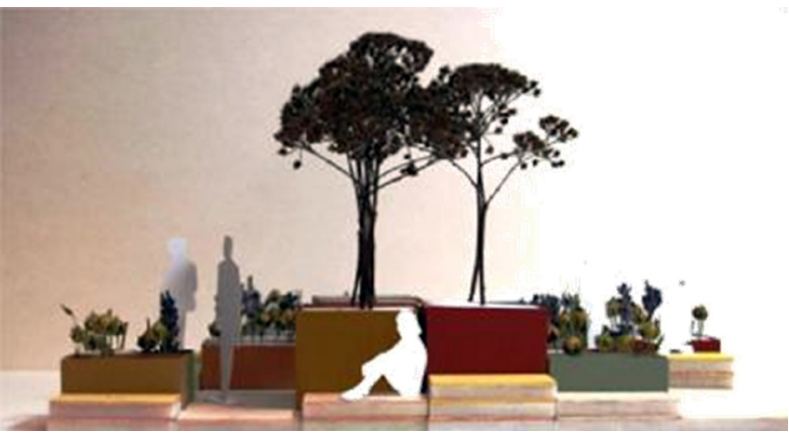

Picture 1. A scale model of the community garden at Liberty Square.

Source: https:/ /generatormalta.wordpress.com/category/ogrody/ogrod-plac-wolnosci/ (accessed: 5 May 2017).

gourds, calabashes, nasturtiums and snapdragons. Seeds were also distributed by the organisers of the project. Seedlings that sprouted on balconies, porches and windowsills were later planted in the gardens at Liberty Square, in the districts of Chwaliszewo, Jeżyce, Łazarz, Wilda and Śródka" (Interview 3, 2016).

The aim of creating the first community garden in the very centre of the city at Liberty Square (Plac Wolności), an area lacking shade and benches, was to offer city residents an opportunity to pause amid greenery, have some rest and take a breather. The organisers provided 100 Europallets, $10 \mathrm{~m}^{3}$ of soil, flowers, trees and bushes to create the community garden in the centre of Poznan. The mobile community garden at Liberty Square enjoyed great popularity among the residents ${ }^{2}$ (Picture 1).

Together with volunteers, the skeleton of the garden was created with Euro-pallets, flowerpots were built from banners and composite wood based panels (OSB) (Picture 2). Expert help was offered by landscape architects. There were also partners: the Liberty Square Association (Stowarzyszenie Plac Wolności) and the Better World Association (Stowarzyszenie Lepszy Świat).

\footnotetext{
In May 2013, Jolanta Starzak and Dawid Strębicki, by adopting recycling, economic and ecological solutions, created the design of a community garden and a scale model which was presented in the social media and during an event launching the project (Picture 1). They also took residents' suggestions and needs into consideration.
}
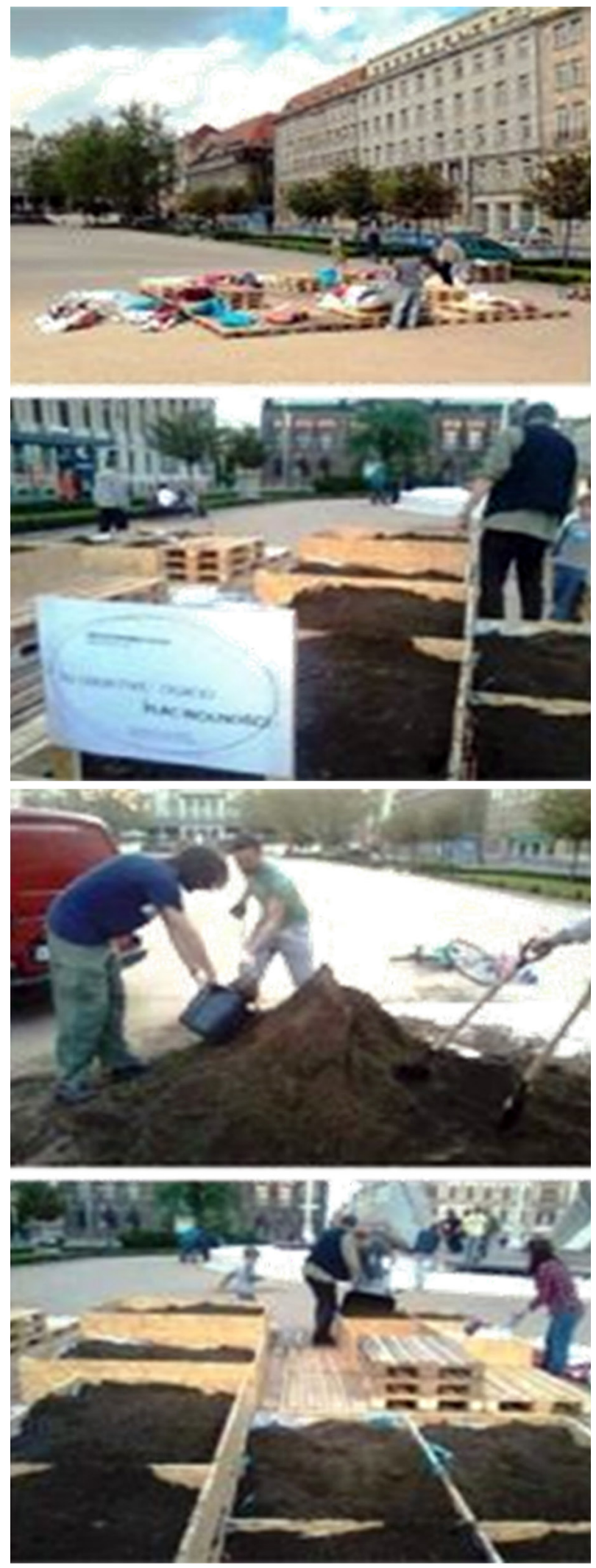

Picture 2. The beginnings of the community garden at Liberty Square in 2013.

Source: https://generatormalta.wordpress.com/category/ogrody/ogrod-plac-wolnosci/ (accessed: 12 April 2018). 
Followers - the 'Bathing Beach' Collective (Kolektyw Kapielisko), Edible Poznań (Jadalny Poznań), Abrys and others

The establishment of community gardens by the Programme of the Generator Malta Festival sparked off further actions to develop the idea of community gardening in Poznań. In 2013, Members of the 'Bathing Beach' Collective Association, inspired by the activities of Generator Malta, got interested in the area of a temporarily closed outdoor summer swimming pool located in Kasprowicz Park.

"For years, the pool was a favourite place of the residents of the Łazarz district; yet, because it became unprofitable, a decision was taken to close it. Since that time, it fell into ruin, which made us - a group of urban activists, deal with this problem" (Interview 2, 2016).

Within the area of the swimming pool, the 'Bathing Beach' Collective Association (Stowarzyszenie Kolektyw Kapielisko) leased a 1300 $\mathrm{m}^{2}$ plot and in 2014 activities were undertaken to develop a community garden (Table 1).

"Rather than discussing we decided to sound out the residents' needs. It means that instead of holding talks during which residents could express their preferences as to what should be developed in a specific area, activities were undertaken to examine how many people would come, participate in the event and get interested in the topic" (Interview 2, 2016).

In this vein, activities focused on plotting plants, distributing seeds and popularising urban food growing were organised.

"The beginnings of the community garden could, therefore, be attributed to a series of educational, artistic and recreational workshops organised in the area of the former swimming pool"(Interview 4 , 2016).

A grant received from Municipal Council was also a significant financial incentive. The city gave the 'Bathing Beach' Collective almost 18,000 PLN for artistic projects to integrate the local community and enrich the cultural life of the district (Pawlak 2017).
Another organiser of the community garden in Poznan was the Foundation for the Preservation of Historic and Natural Monuments (Fundacja Ratowania Zabytków $i$ Pomników Przyrody). It functions as part of the project - Edible Poznan (Jadalny Poznań). The first community garden created thanks to this initiative was opened in May 2014 in the district of Sołacz, the Nad Potokiem estate. The second was established next to the socio-educational centre for deaf children in Poznańskie Wzgórze Reformatów in the district of Śródka. The major principle of the garden in Solacz is the following: "in exchange for weeding and planting you can take the yields" (www.epoznan.pl). This project facilitates neighbourly integration and helps to replace monotonous lawns in housing estates with areas full of vegetables, fruit, herbs and flowers (www.epoznan.pl). In the future, Edible Poznań is planning to establish community gardens in other Poznań locations: in the districts of Piątkowo and Winiary. The Foundation for the Preservation of Historic and Natural Monuments deals with the collection of necessary financial sources. Funds are raised thanks to crowdfunding (https://www.facebook.com/ogrody.spoleczne/).

In 2016, the initiative for developing the idea of community gardening in Poznan, in cooperation with the Housing Cooperative 'Osiedle Młodych' (an entity for the administration and maintenance of a housing estate), was undertaken by Abrys - a private company dealing with education, ecology and environmental protection. In 2017, it launched a community garden on the Os. Czecha housing estate (Table 1). So far it has been the only place of this type in the Nowe Miasto district.

Furthermore, in the autumn of 2017, a municipal budget entity - the Urban Greenery Board, when revitalising a city park - Jan Heweliusz Park, established the Grunwaldzki Community Garden (Grunwaldzki Ogród Społeczny - www. lokalnyfyrtel.pl). The initiator of the concept was a private person who submitted the idea to the participatory budget. In the meantime, the Szeląg Beach-Garden (Ogród Plaża Szelag), established among others by an NGO, and the non-profit organisation, the Wilczak Mobile Culture Centre (Mobilny Dom Kultury Wilczak), started its activity. 


\section{Present-day}

The research has shown that due to various reasons some of the community gardens in Poznań stopped functioning quite quickly. These were: the Liberty Square Garden (Ogród Plac Wolności), the Śródka Republic (Republika Śródka) and the Chwaliszewo Garden (Ogród Chwaliszewo) (Table 1, Fig. 4).

Despite careful preparation and major development taking place in the community garden at Liberty Square, some problems started to arise (Pawlak 2017).

"It happened so because the centre is a place visited by a considerable number of people both residents and tourists; and the public space of Liberty Square can in no way be controlled or taken care of by neighbours. As a result there are ample opportunities for theft. Thieves dug up seedlings of not only the more expensive species but also of those cheap ones, for instance, thujas and pansies. The aim of the project (i.e. bringing back the green heart to the city and making space for meeting, creating and cooperating) was achieved. However, the seedlings survived only a year and the thefts of plants forced us to give up the idea of gardening and started stimulating other kinds of activity in the square “. (Interview 2, 2016)

Also the area allocated for a community garden in Chwaliszewo stopped serving its functions rather quickly; the organisers decided not to continue the project here because of the development of KontenerArt - a cultural, artistic and recreational centre.

"Only very few people were interested in the garden in Chwaliszewo and a significant proportion of dwellers was afraid that another meeting place for the young could lead to noise and different pathologies. Some residents got more engaged in creating KontenerArt and the idea of plant beds was marginalised. A conflict arose among residents who were afraid of additional noise; consequently we decided that, maintaining the garden against the residents would be contrary to its purpose of integrating society and building a community" (Interview 2, 2016).

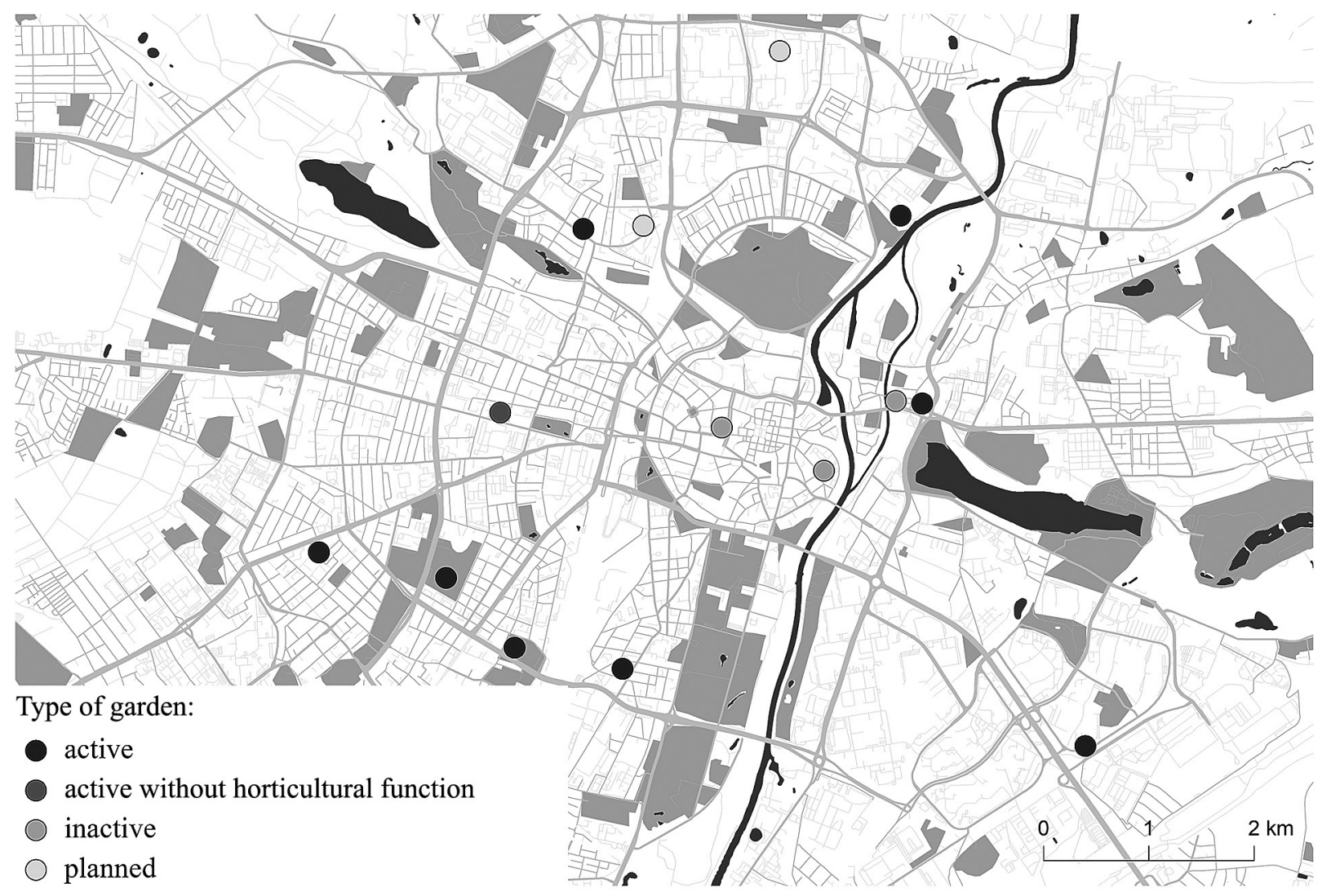

Fig. 4. Distribution of community gardens in Poznań. Source: own compilation. 
The community garden of Śródka did not survive the test of time either and only a single pot stands there as a testimony to the existence of a former community garden. One of the reasons is the increasingly tourist character of this place. The opening of the Porta Poznania Interactive Cathedral Island Heritage Centre of Poznań ICHOT (Brama Poznania Interaktywne Centrum Historii Ostrowa Tumskiego ICHOT) in 2014 contributed to a significant increase in the number of both Polish and foreign tourists, i.e. external space users visiting the Śródka district.

In addition, in the Jeżyce garden (Ogród Jeżyce), only occasional events are held now connected with ecology or farming and no plants are grown there any longer. Nevertheless, the lack of beds or boxes with seedlings is noticeable. An important element of development is a renovated kiosk where residents meet, read together, exchange books and listen to music. It seems that in this case the joint cultivation was just a pretext to establish a local artistic community which currently focuses mainly on cultural activities which take place in or next to the kiosk.

Accordingly, at the end of 2017, there were 9 active community gardens in Poznan located in the following districts: Łazarz, Wilda, Sołacz, Jeżyce, Śródka, Nowe Miasto, Grunwald and Wilczak (Fig. 4). The figure clearly shows that the gardens which operated in 2013 and which are now inactive tended to be closer to the city centre than the gardens functioning now. Thus, it seems that in the case of Poznan, the closer to the city centre, the more threats to the functioning of a community garden due to a greater number of people flowing through public space. In spaces common to all city residents but also to external users (e.g. tourists), located in the city centre filled with high-order services, community gardens failed to succeed.

However, community gardens which are active but further from the centre have also numerous problems at present to contend with. The Wilda Community Garden (Ogród Wilda), originally planned as open to the public, has become a meeting place for suspected individuals. In consequence, its infrastructure is being damaged and rubbish appears. A similar problem, yet to a lesser degree, is present in the community garden of Łazarz (Ogród Łazarz). This may be partly because both initiatives did not come directly from the residents but were established by Generator Malta.

An interesting and at the same time disturbing phenomenon occurs in the community garden of the 'Bathing Beach' Collective. The garden was created when the summer city swimming pool was abandoned and closed. At present, the facility is modernised and available to residents. However, the community garden of the 'Bathing Beach' Collective received a lease termination notice from the municipal budget entity, the Poznań City Sports and Leisure Centre (Poznański Ośrodek Sportu i Rekreacji), and its future is uncertain.

"Thanks to our initiative, this place has revived, and thus obviously has become more attractive. Now the city authorities see other more desirable users of the space occupied by our garden" (Interview 7, 2018).

\section{Community gardens in the Łazarz district - types of activities}

In order to analyse closely the events organised in the community gardens in Poznan, gardens from the Łazarz district were selected. In this area, the number of gardens and activities undertaken is the largest. Moreover, gardens selected for the analysis were established almost at the same time. However, both these initiatives were of different character. The Łazarz Garden was founded by Generator Malta so it was a kind of top-down action. Whereas setting up the 'Bathing Beach' Collective community garden was a bottom-up activity. Interestingly though, people involved in setting up this garden came mainly from outside the district.

It is not without a reason that the creators of the Generator Malta Programme (Program Generatora Malta) and the 'Bathing Beach' Collective Association decided to establish community gardens in Łazarz. According to statistical data, over 11,000 people have left this district since 2000 (www.lazarz.pl). Furthermore, opinion polls carried out by the 'Bathing Beach' Collective among the residents revealed that the district of Łazarz had a very narrow range of cultural events. In addition, the residents expressed the need to participate in the local life. 


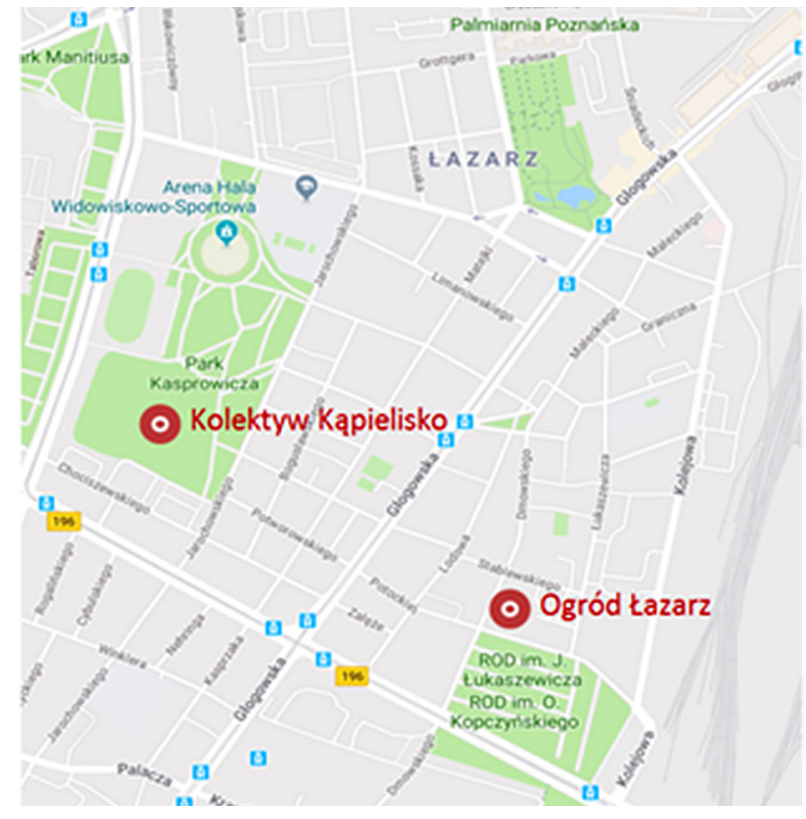

Fig. 5. Community gardens in the Łazarz district . Source: own compilation.

The analysis concerned activities which took place in the community gardens of Łazarz (Fig. 5), i.e. the Łazarz Garden and the 'Bathing Beach' Collective in the years 2014-2017. The number and character of meetings were determined on the basis of internet information posted by the organisers of both gardens on social networking sites. All the events that took place in the gardens revealed the character of the activities which can be divided into the following categories: horticultural, artistic, recreational, craft, environmental and educational, entrepreneurial and others (Table 2). This division was meant to emphasise the major functions served by a given community garden for residents.

\section{Community garden - the Eazarz Garden}

In the period under analysis, various events in the Łazarz Garden took place mostly during summer months, i.e. from June to September, on average twice a week. From 2014 to 2017, there were as many as 110 meetings on the premises of the garden and $40 \%$ of them had the character of artistic events (Fig. 6). Most of them were concerts, art workshops and theatrical performances (Picture 3). Another 34\% of the events were connected with recreation: common feasts, picnics and an outdoor cinema. Those devoted to garden farming made up $12 \%$ of all meetings, and the ones concerning DIY and the development of garden furniture $-6 \%$. Events related to environmental education amounted to $5 \%$ and those belonging to the category of 'others' (among others, yoga classes, dance workshops, charity sales) made up $3 \%$ of all meetings.

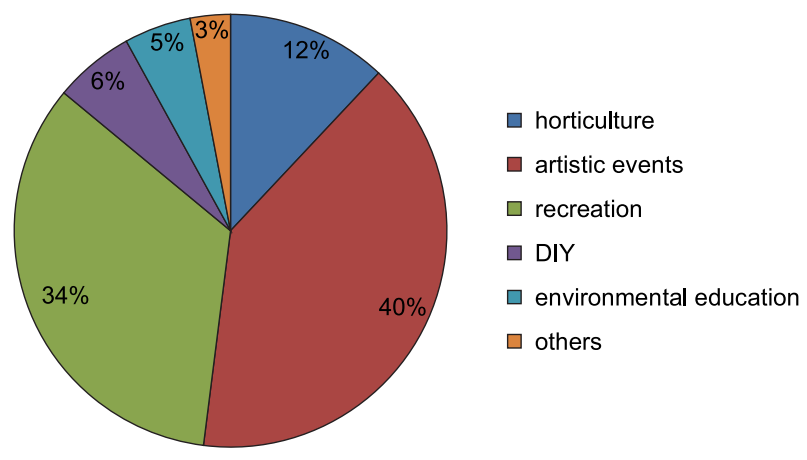

Fig. 6. Types of events in the Łazarz Garden in Poznań in the years 2014-2017.

Source: own compilation.

Table 2. Types of events organised in community gardens.

\begin{tabular}{|c|c|c|c|c|c|c|}
\hline Horticulture & $\begin{array}{l}\text { Artistic } \\
\text { events }\end{array}$ & Recreation & DIY & $\begin{array}{l}\text { Environmental } \\
\text { education }\end{array}$ & Entrepreneurship & Others \\
\hline $\begin{array}{l}\text { all types of } \\
\text { work connect- } \\
\text { ed with plant- } \\
\text { ing, weeding, } \\
\text { growing seed- } \\
\text { lings in pots, } \\
\text { fertilising soil, } \\
\text { taking care of } \\
\text { composter, } \\
\text { raking, tidying } \\
\text { the garden, } \\
\text { watering. }\end{array}$ & $\begin{array}{l}\text { workshops, } \\
\text { photo and } \\
\text { art contests, } \\
\text { theatrical } \\
\text { events as } \\
\text { well as other } \\
\text { events con- } \\
\text { nected with } \\
\text { art. }\end{array}$ & $\begin{array}{l}\text { feasts, } \\
\text { picnics, } \\
\text { camping, } \\
\text { outdoor cin- } \\
\text { ema, other } \\
\text { recreational } \\
\text { activities, } \\
\text { e.g. birthday } \\
\text { parties. }\end{array}$ & $\begin{array}{l}\text { all types of work } \\
\text { connected with } \\
\text { production of } \\
\text { furniture, devel- } \\
\text { opment of gar- } \\
\text { den infrastruc- } \\
\text { ture, construction } \\
\text { of hiding-places } \\
\text { for children, } \\
\text { storehouses, } \\
\text { larders as well as } \\
\text { workshops teach- } \\
\text { ing carpentry }\end{array}$ & $\begin{array}{l}\text { events helping } \\
\text { to build ecolog- } \\
\text { ical awareness } \\
\text { and broadening } \\
\text { knowledge of } \\
\text { ecology, ani- } \\
\text { mals, plants }\end{array}$ & $\begin{array}{l}\text { events during } \\
\text { which garden users } \\
\text { exchange or sell } \\
\text { their produce and } \\
\text { products, fruit and } \\
\text { vegetable pre- } \\
\text { serves, or unused } \\
\text { objects and clothes. }\end{array}$ & $\begin{array}{l}\text { dance } \\
\text { classes and } \\
\text { workshops } \\
\text { on differ- } \\
\text { ent games, } \\
\text { sports } \\
\text { disciplines } \\
\text { as well as } \\
\text { charity sales. }\end{array}$ \\
\hline
\end{tabular}

Source: own compilation. 


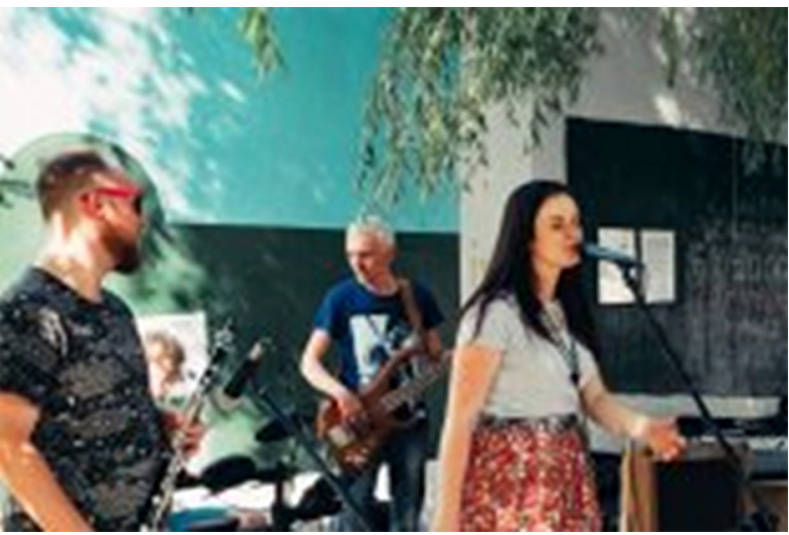

Picture 3. "ŁAZART" street art festival in the Łazarz Garden.

Source: 'Circle' Residents' Club. https:/ / klubkrag.pl/?menu=60\&ID=2303.

\section{Community garden - the 'Bathing Beach' Collective}

In the examined period, the events organised in the community garden the 'Bathing Beach' Collective were held in the summer season from May to September, on average once a week. They also took place on holidays, for instance, on Children's Day. There were also a few-day-long cycles of meetings. The 'Bathing Beach' Collective has initiated 80 events in the area of Kasprowicz Park since the beginning of its garden-related activity, i.e. since May 2014. The number did not include organisers' meetings in the neighbouring 'Circle' Residents' Club which concerned garden issues. In view of the conducted analysis, it is clear that the greatest number of events organised in the 'Bathing Beach' Collective community garden were connected with gardening activities - 25\% (Fig. 7). Much time was devoted to the development of garden infrastructure since as many as $20 \%$ of all meetings concerned the

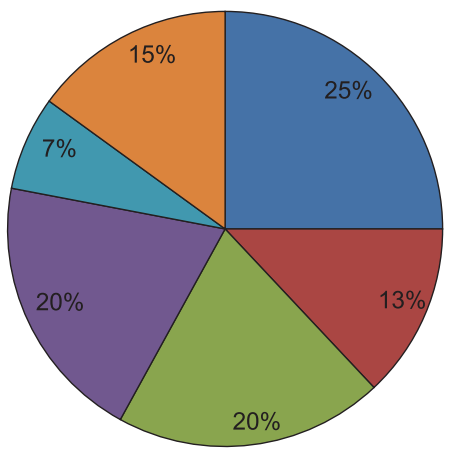

$\square$ horticulture

$\square$ artistic events

$\square$ recreation

$\square$ DIY

$\square$ environmental educatior

$\square$ others

Fig. 7. Types of events in the 'Bathing Beach' Collective in Poznań in the years 2014-2017. Source: own compilation.

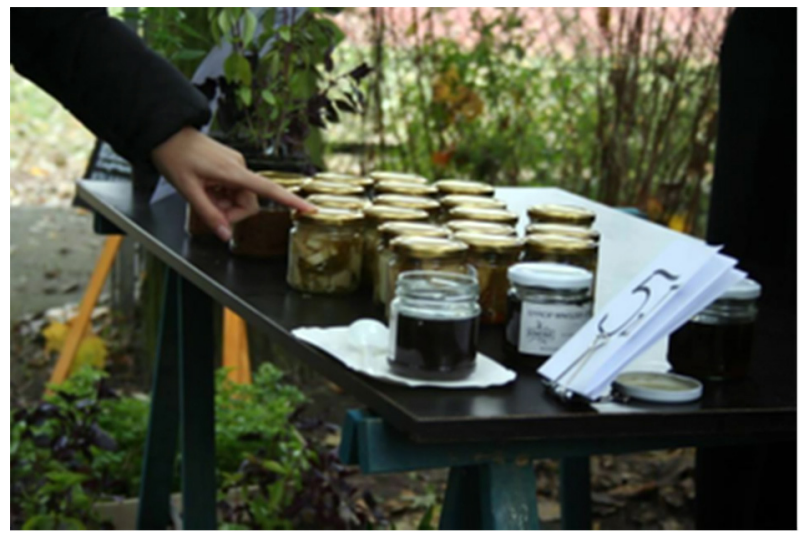

Picture 4. Preserves market in the 'Bathing Beach' Collective.

Source: Krystyna Pawlak (author).

production of garden furniture and garden street architecture. Just as many events had a recreational character - residents had common feasts and could integrate with one another. Still other events, specific for a given garden, were events promoting entrepreneurship - 15\%. Some other events, popular with garden users, were garage sales, preserves fairs as well as professional workshops. Artistic as well as educational and environmental activities made up the lowest percentage of all events -13 and $7 \%$ respectively.

\section{Comparison of gardens}

When comparing the activities of the two community gardens situated in the same district of Łazarz, one can come to a conclusion that both gardens have a multifunctional character, although the structure of the events held there differs significantly. This dissimilarity may be attributed to many factors such as: location, direct neighbourhood, area, area type (e.g. transitive, separated), infrastructure, profile of the initiating entity, cooperating units.

In the 'Bathing Beach' Collective the structure of the implemented activities was more diverse and balanced (Fig. 7, Fig. 8). In addition, the events organised in this garden implemented all four major functions of community gardens: social, economic, territorial and environmental (Fig. 2), whereas in the Łazarz Garden, the structure of activities was dominated by artistic events, recreation and integration, which accounted for almost $3 / 4$ of all actions (Fig. 6). What is more, in this community garden activities related to the development of entrepreneurship were not implemented. It seems that several factors have 


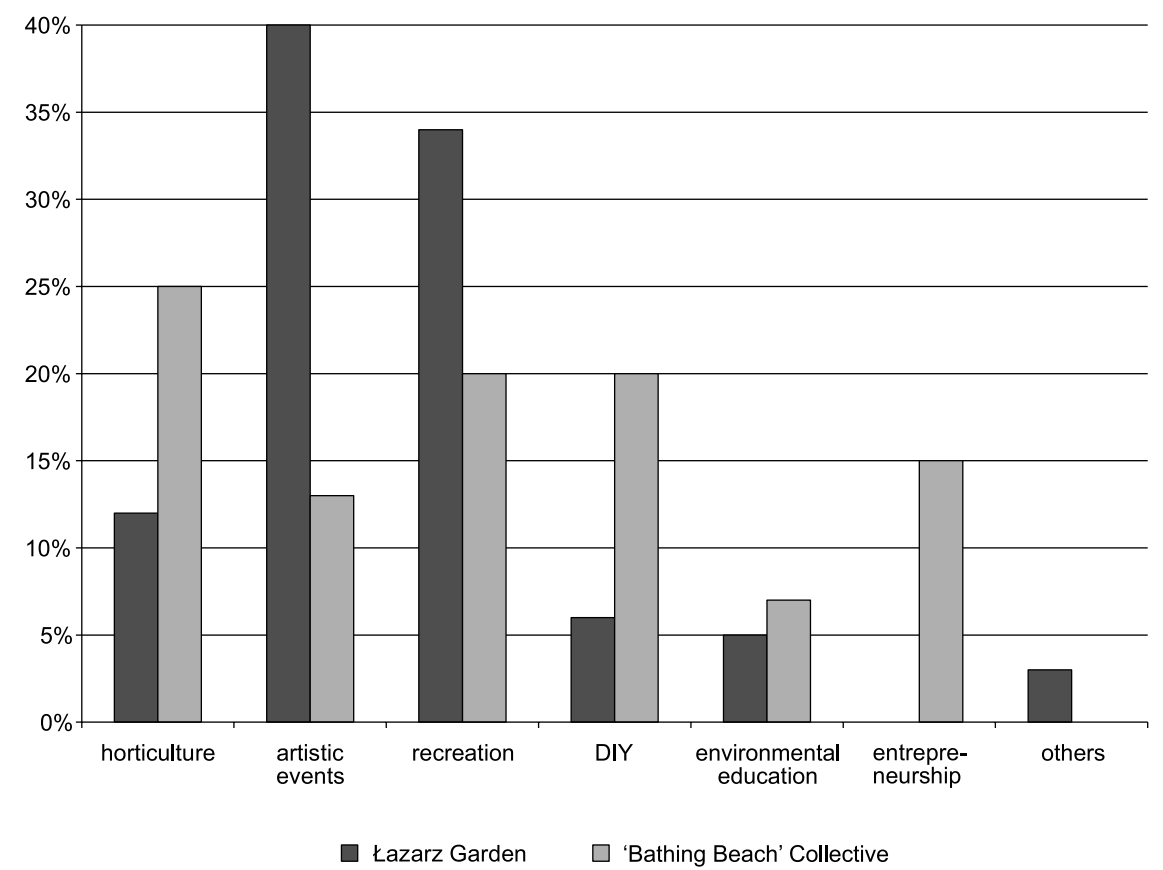

Fig. 8. Types of events held in community gardens in the district of Łazarz in the years 2014-2017. Source: own compilation.
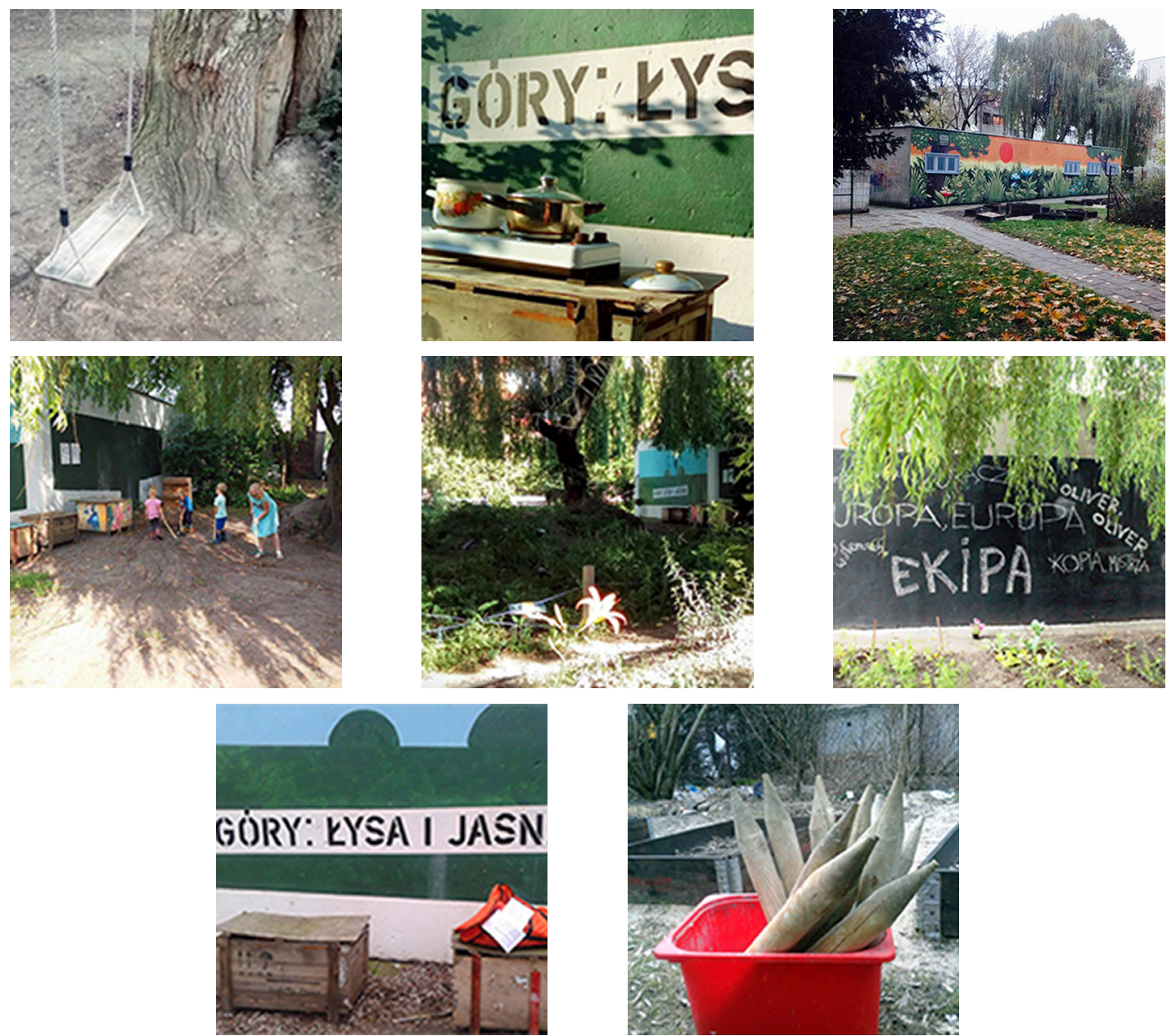

Picture 5. Garden greenery and infrastructure - Łazarz Garden.

Source: photos taken by Pola Kowalczyk, Krystyna Pawlak, Janusz Haller, Natalia Wisłocka. 
contributed to this structure of events in the Łazarz Garden. First of all, this garden was initiated by the Generator Malta programme which, as part of the Malta Festival, is strongly associated with the organisation of cultural events. What is more, the Łazarz Garden maintains close cooperation with the neighbouring 'Circle' Residents' Club which is a local culture centre. The location of the Łazarz Garden in the immediate vicinity of blocks of flats and culture centre favours the organisation of recreational neighbourhood events.
In addition, the lack of a clear separation of the garden area from the surrounding space, i.e. transitive character of the place hinders cultivation as well as adversely influences the development of garden infrastructure (Fig. 5). The above-mentioned reasons certainly account for the fact that gardening was not the main activity undertaken in the Łazarz Garden.

The situation of the 'Bathing Beach' Collective garden is different. The larger area of the garden and its fence protection guarantee more space
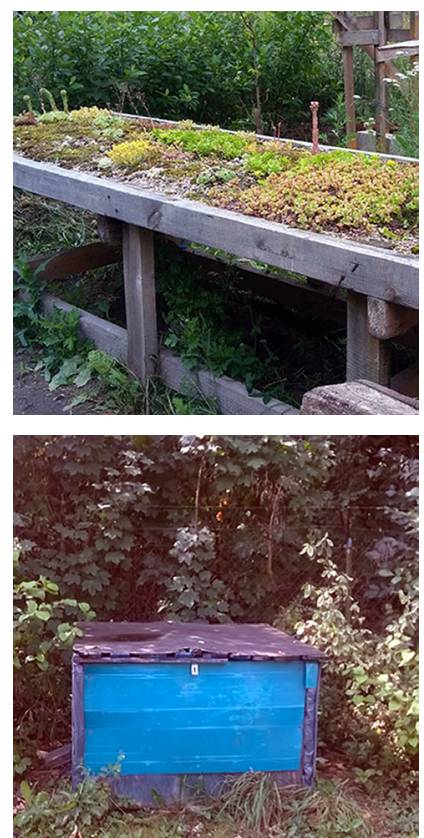
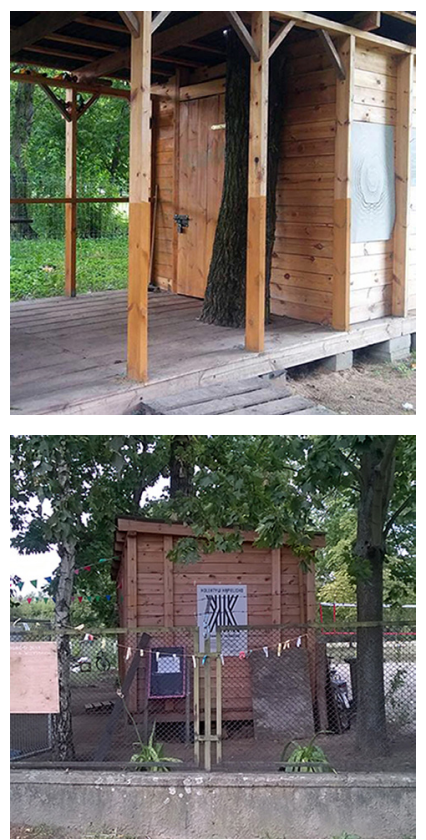
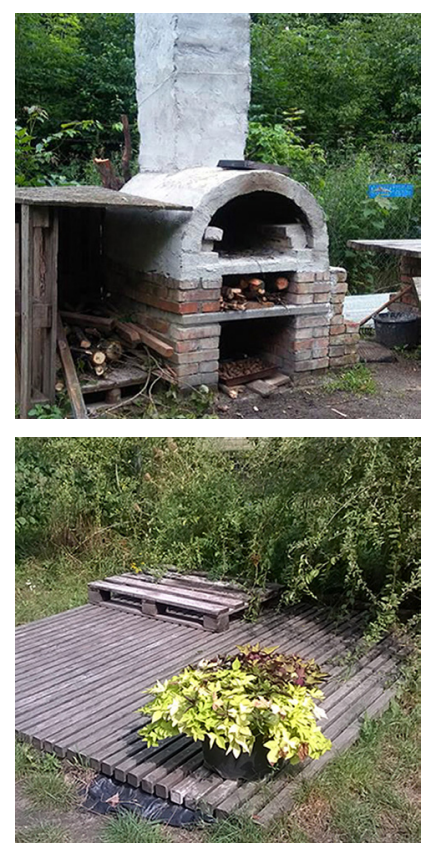
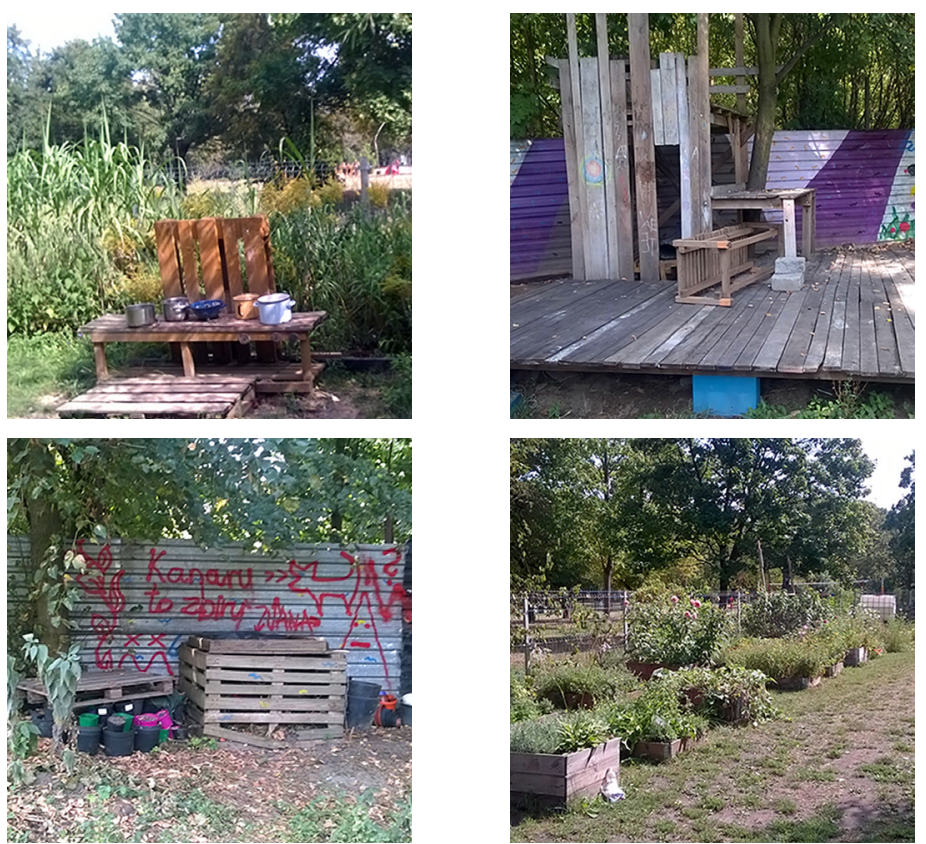

Picture 6. Garden greenery and infrastructure - the 'Bathing Beach' Collective. Source: photos taken by the authors. 
for agricultural activity as well as the security of crops and infrastructure (Fig. 6). A higher level of security makes the organisation of entrepreneurial events easier. They were only held in the garden of the 'Bathing Beach' Collective and took the form of an exchange and sale of preserves, books and clothes (for instance, as part of garage sales or preserves markets (Fig. 4). The more diversified and balanced structure of the events organised in the garden was also determined by the fact that it was a grassroots initiative of a group of various people, i.e. with different backgrounds, education and interests, united around the idea of urban space revitalisation and the integration of the local community through joint activities in a community garden.

\section{Conclusions}

The research conducted reveals clearly that community gardens in Poznań were initiated most of all by a variety of different NGOs. To a much smaller degree, they were also created on the initiative of a private company, housing cooperative and municipal budget entity - the Urban Greenery Board (Zarzad Zieleni Miejskiej). None of the Poznan community gardens was established as part of nationwide projects promoting the development of community gardening, i.e. Our Community Garden (Nasz Ogród Społeczny) or Cultural Wasteland (Nieużytki Sztuki). Not all the gardens created in Poznań were the result of grassroots initiatives, typical of community gardens. Five out of twelve gardens were created as a consequence of bottom-up activities, the remaining ones were more or less the effect of topdown actions.

The largest number of community gardens was created thanks to the initiative of the Generator Malta programme which was launched as part of the Malta Festival. Undoubtedly, it was Generator Malta that gave a strong impulse for the development of community gardens. Established in 2013 Generator's gardens were the first of this type in Poznań. Unfortunately, only half of them survived the test of time. The ones situated in the very centre of the city ceased functioning rather quickly, since, as a common space for all city residents and also for external users (e.g. tourists), filled with high-order services, the centre turned out to be unfavourable for the development of community gardens.

Currently, as many as 9 community gardens continue to function in the city of Poznań. There are also plans to establish some new ones. With the exception of the district of Łazarz in which there are two community gardens, the other ones are scattered in different parts of the city. The reasons for the existence of two gardens in this district are, among others, a quick outflow of people from Łazarz and its very poor cultural offer.

The locations selected for building community gardens in Poznań were markedly different. Nevertheless, those were most frequently undeveloped or neglected plots situated between old residential blocks or tenements. Two of them were established in uncontrolled greenery close to the Warta River and another two in city parks. Currently, the future of one of the gardens that has been particularly successful in revitalising the city space is threatened. The 'Bathing Beach' Collective community garden was created when the summer city swimming pool in Kasprowicz Park in Poznań was abandoned and closed; at present, the facility is modernised and available to residents. Thanks to the community gardening initiative, this place revived, and thus obviously became more attractive. Now the city authorities see other, more desirable users of the space occupied by the garden.

A detailed examination of the meetings that took place in the Łazarz community gardens in the years 2014-2017 shows that both gardens have a multifunctional character, although the structure of the events held there differs significantly. In the 'Bathing Beach' Collective the organisation of the implemented activities was more diverse and balanced. In addition, the events organised in this garden implemented all four major functions of community gardens: social, economic, territorial and environmental, whereas in the Łazarz Garden, the structure of activities was dominated by artistic events, recreation and integration, which accounted for almost $3 / 4$ of all actions. What is more, in this community garden activities related to the development of entrepreneurship were not conducted.

In conclusion, we would like to emphasise that the creation and maintenance of community gardens should be considered almost as acupuncture interventions for an urban and social 
improvement of the city. Moreover, urban community gardens generate a new city model, not only in spatial but also in human terms.

Currently, when the multifunctionality of the urban space is valued and there is a constant talk of a crisis of public spaces, urban agriculture, and especially urban community gardens, strengthen the social fabric of neighbourhoods by making them alive and giving them identity endowed with content and loaded with symbolism about the past and the future.

The community gardens themselves will not solve all the social, economic, territorial and environmental problems of cities, but they will certainly contribute in different ways to the improvement in all these areas. The statements of Henri Lefebvre (1968) are worth remembering. He stated that "it is necessary to restore the sense of city, establish the possibility of good living for all, and make the city the meeting place for the construction of collective life." The Lefebvre's right to the city "is not simply the right to what is already in the city, but the right to transform the city into something radically different" (Harvey 2009).

\section{Acknowledgements}

Special thanks go to Ms Joanna Pańczak, a curator of the Generator Malta Programme whose help in preparing this article was invaluable. But for your knowledge, patience and time, it would never have been written. We beg your forgiveness yet, if some aspects of the subject matter discussed here were excessively simplified. We also express heartfelt gratitude to the 'Bathing Beach' Collective: Klaudia Lewczuk, Agnieszka Malinowska, Aleksandra Dolczewska, Magdalena Garczarczyk, Justyna Pers, Joanna Januszewska and Jolanta Starzak. Many thanks for your time, experience, exchange of thoughts and discussions in the garden.

\section{References}

Aubry C., Pourias J., 2013. L'agriculture urbaine fait déjà partie du métabolisme urbain. Club Demeter Editeur, Paris: 135-155.

Anthopoulou T., 2012. Urban agriculture, social inclusion and sustainable cities: Case study of two municipal gardens in
Northern Greece. Panteion University of Social and Political Science, Athens.

Boukharaeva L., Marloie M., 2010. L'apport du jardinage urbain de Russie à la théorisation de l'agriculture urbaine. VertigO-la revue électronique en sciences de l'environnement 10 (2). DOI : $10.4000 /$ vertigo.13819.

Busquets I., Fàbregas J., 2008. Guia d'integració paisatgística 2. Horts urbans i periurbans. Departamento de Política Territorial y Obras Públicas, Generalitat de Catalunya, Barcelona.

Bradley K., Galt R.E., 2014. Practicing food justice at Dig Deep Farms \& Produce, East Bay Area, California: Self-determination as a guiding value and intersections with foodie logics. Local Environment 19(2): 172-186.

Caputo S., Schwab E., Tsiambaos K., Benson M., Bonnavaud H., Demircan N., Pourias J., 2016. Emergent approaches to urban gardening. In: Bell S., Fox-Kämper R., Keshavarz N., Benson M., Caputo S., Noori S., Voigt A. (eds), Urban allotment gardens in Europe. Routledge, London/ New York: 229-253.

Duchemin E., Wegmuller F., Legault A.M., 2009. Urban agriculture: Multi-dimensional tools for social development in poor neighbourhoods. Field Actions Science Reports (2): 1-8.

Fernández Casadevante J.L., Morán N., 2015. Raíces en el asfalto: pasado, presente y futuro de la agricultura urbana. Libros en acción, Madrid.

Giedrych R., Poniży L., 2013. Ogrody działkowe jako przedmiot polityki przestrzennej i ekologicznej miast na przykładzie Warszawy i Poznania (Allotment gardens as the subject of the spatial and ecological policy of cities on the example of Warsaw and Poznań). In: Kosmala M. (ed.), Ogrody działkowe w miastach - bariera czy wartość? (Allotment gardens in cities - barrier or value). PZIiTS, Torun: 23-33.

Harvey D., 2009. Conferencia de apertura en el marco del Seminario sobre Reforma Urbana en el Forum Social Mundial 2009. Belém do Para, Brasil.

Kałużna D., Mizgajski A., 2016. Community gardens in Poland - Impulse, assistance, expansion. In: Tappert S. (ed.), Growing in cities. Interdisciplinary perspectives on urban gardening. Conference proceedings. University of Applied Sciences, Basel: 106-118.

Latkowska M.J., 2012. „Community gardens” , czyli ogrody sąsiedzkie - nowe formy zieleni w przestrzeni miejskiej ('Community gardens' or neighbouring gardens - new forms of greenery in the urban space). Czasopismo Techniczne Architektura 6A(19): 271-276.

Latkowska M.J., 2016. Zielony trend. Moda na ogrody społeczne w Polsce (A green trend. Fashion for community gardens in Poland). Online: http://docplayer. pl/22303075-Zielony-trend-moda-na-ogrody-spolecznew-polsce.html (accessed: 10 August 2018).

Lefebvre H., 1968. Le droit à la Ville. Éditions du Seuil, Collection Points, Paris.

Lefebvre H., 1972. Le droit à la ville suivi de l'espace et politique. Anthropos, Paris.

Maćkiewicz B., Szczepańska M., 2017. Tereny zieleni a nazwy inwestycji deweloperskich w Poznaniu (Green areas and the names of development investments in Poznań). Rozwój Regionalny i Polityka Regionalna 40: 227-241.

Maćkiewicz B., Andrzejewski A., Kacprzak E., 2018. Koszty bezładu przestrzennego dla rynku nieruchomości (Spatial disorder costs for the real estate market). Studia KPZK PAN 182(2): 280-312. 
McKay G., 2011. Radical gardening: Politics, idealism and rebellion in the garden. Frances Lincoln, London.

Moran N., Fernández Casadevante J.L., 2012. Cultivar la resiliencia. Los aportes de la agricultura urbana a las Ciudades en Transición. Papeles de relaciones ecosociales y cambio global 119: 131-143.

Orzechowska-Szajda I., Podolska A., 2013. Estetyka zagospodarowania ogrodów działkowych w Polsce i Niemczech - studium porównawcze dwóch ogrodów (Aesthetics of allotment development in Poland and Germany - a comparative study of two allotments). In: Kosmala M. (ed.), Ogrody działkowe a miastach - bariera czy wartość? (Allotments in cities - barrier or value?) PZIiTS, Torun: 81-96.

Pawlak K., 2017. Ogrody społeczne w Poznaniu (Community gardens in Poznań). Master's thesis manuscript.

Pokorski J., Siwiec A., 1998. Kształtowanie terenów zieleni (Shaping green areas). Wydawnictwa Szkolne i Pedagogiczne, Warszawa.

Reyburn S., 2002. Le cadre de vie et les jardins potagers communautaires à Montréal. VertigO - la revue électronique en sciences de l'environnement 3(2): DOI: 10.4000/vertigo.3794.

Rosol M., 2012a. Chapter 7 Grassroots gardening initiatives: Community gardens in Berlin. In: Davies A. (ed.), Enterprising communities: Grassroots sustainability innovations. Emerald Group Publishing Limited, Bingley: 123-143.

Rosol M., 2012b. Community volunteering as neoliberal strategy? Green space production in Berlin. Antipode 44(1): 239-257.

Skrzypczak B., 2017a. Ogród sąsiedzki - miejsce które skupia ludzi (A neighbouring garden - a place that brings people together). Online: http://warszawalokalnie. waw.pl/wp-content/uploads/2016/08/Ogr\%C3\%B3ds\%C4\% 85siedzki-\%E2\% 80\%93-miejsce-kt\%C3\%B3reskupia-ludzi.pdf (accessed: 25 August 2018).

Skrzypczak B., 2017b. Raport CAL „Maszyny społeczne” na placu budowy wspólnot lokalnych Warszawy (the CAL report 'Social machines' on the construction site of Warsaw's local communities), Warszawskie Laboratorium Innowacji Lokalnych, Warszawa.

Smit J., Ratta A., Nasr J., 1996. Urban agriculture: Food, jobs and sustainable cities. Publication Series for Habitat II, Vol. I. United Nations Development Programme (UNDP), New York.

Sondermann M., Morán N., Ioannou B., 2016. Grassroots gardening movements: Towards cooperative forms of green urban development? In: Bell S., Fox-Kämper R., Keshavarz N., Benson M., Caputo S., Noori S., Voigt A. (eds), Urban allotment gardens in Europe. Routledge, London/ New York: 84-112.

Shillington L.J., 2013. Right to food, right to the city: Household urban agriculture and socionatural metabolism in Managua, Nicaragua. Geoforum 44(1): 103-111.

Speak A.F., Mizgajski A., Borysiak J., 2015. Allotment gardens and parks: Provision of ecosystem services with an emphasis on biodiversity. Urban Forestry EUrban Greening 14: 772-781.

Szkup R., 2013. Użytkowanie rodzinnych ogrodów działkowych (ROD) przez społeczność wielkomiejską: Przykład Łodzi (Use of family allotments (ROD) by a metropolitan community: A case of Łódź). Wydawnictwo UŁ, Łódź.

Toledo V.M., Barrera-Bassols N., 2008. La memoria biocultural: La importancia ecológica de las sabidurías tradicionales. Icaria, Barcelona.
Tornaghi C., 2017. Urban agriculture in the food-disabling city: (Re)defining urban food justice, reimagining a politics of empowerment. Antipode 49(3): 781-801.

Ustawa $z$ dnia 13 grudnia 2013 r. o rodzinnych ogrodach działkowych (Act of December 13, 2013 on family allotment gardens, Journal of Laws of 2014, item 40).

\section{Online sources}

www.bujnawarszawa.pl (accessed: 15 September 2018).

http:/ / epoznan.pl/news-news-74429-W_Poznaniu_powstana_ogrody_spoleczne (accessed: 20 August 2018).

h t t p s : / / w w w . f a c e b o o k. com / pa ges / Ogr\%C3\%B3d-Wilda/319608048190513?fref $=$ ts $\quad$ (accessed: 12 September 2018). https://www.facebook. $\mathrm{com} / \mathrm{pg} /$ ilustradoradorailustra/photos/?ref=page_internal (accessed: 5 September 2018).

https://www.facebook.com/grunwaldzkiogrod/ (accessed: 20 July 2018).

https://www.facebook.com/groups/540247426026208/?fref $=$ ts (accessed: 20 August 2018).

https://www.facebook.com/kolektywkapielisko/ (accessed: 20 September 2018).

https:/ / www.facebook.com/ogrody.spoleczne/?fref=ts (accessed: 29 August 2018).

https:/ / www.facebook.com/OgrodSpolecznynaOsiedluCzecha/ (accessed: 22 August 2018).

https://www.facebook.com/plazaogrodszelag/ (accessed: 27 August 2018).

https://generatormalta.wordpress.com/category/ogrody/ ogrod-plac-wolnosci/ (accessed: 22 September 2018).

http://greencrosspoland.org/ (accessed: 10 September 2018).

http:/ / krakow.pl/aktualnosci/217700,29,komunikat,ogrody_spoleczne_uatrakcyjnia_blokowiska.html (accessed: 20 August 2018).

http:// kolektyw-kapielisko.tumblr.com/ (accessed: 15 September 2018).

http:/ / lokalnyfyrtel.pl/wydarzenie/cykl-spotkan-w-ogrodach-spolecznych/ (accessed: 10 September 2018)

http://lazarz.pl/?id=2\&nr=4282 (accessed: 11 September 2018).

http:// malta-festival.pl/pl/program/generator/ogrody-spoleczne-2 (accessed: 20 August 2018).

www.naszogrodspoleczny.pl/ (accessed: 12 October 2017).

http:/ / nieuzytkisztuki.elajablonska.com/ (accessed: 10 September 2018).

http://ogrodynh.pl (accessed: 10 September 2018)

http:/ / osiedlemlodych.pl/stworzmy-ogrod-spoleczny-naos-czecha/ (accessed: 10 September 2017).

http:/ / poznan.naszemiasto.pl/tag/jadalny-poznan.html (accessed: 15 September 2017).

http:/ / ulicaekologiczna.pl/ przyroda/kolektyw-kapielisko (accessed: 07 August 2018)

http://www.um.warszawa.pl/en/aktualnosci/ogrodyspo-eczno-ciowe-czyli-zr-bmy-razem (accessed: 4 May 2018).

http:/ / warszawa.naszemiasto.pl/artykul/ogrody-spoleczne-w-warszawie-tutaj-oddasz-sie-uprawie,3743392,galop,t,id,tm.html (accessed: 22 September 2018). 